\title{
PREDICTION AND FOREKNOWLEDGE IN EZEKIEL'S PROPHECY AGAINST TYRE
}

\author{
Kris J. Udd
}

\begin{abstract}
Summary
Ezekiel's prophecy that Tyre would be destroyed by Nebuchadnezzar was not fulfilled in the manner predicted by the prophet. This is demonstrated from extra-biblical literature, supported by archaeological evidence, and acknowledged by Ezekiel himself in a later prophecy. As a result, it is argued that the passage supports a world-view in which God is sometimes willing to adjust his plan from what he initially declared. This supports a relational view over the conventional deterministic view of divine foreknowledge, and it helps ease the tension between the test of a true prophet and a true prophet whose prediction is not fully realised.
\end{abstract}

\section{Introduction}

When Ezekiel prophesied the imminent doom of the city of Tyre (Ezek. 26:1-21), many Israelites must have been elated. Jerusalem was nearing the end of a siege by the Babylonians, a siege that would end in the fall of the city and the deportation of much of her population. However, with the passage of time it became clear that the prophecy against Tyre would not be fully realized. There must have been some real headscratching among faithful Israelites. The failure of Ezekiel's prophecy continues to present some challenging questions to Christians today.

\section{The City of Tyre}

Ancient Tyre was a powerful trading centre located on the Mediterranean coast north of Israel. The city was securely situated on 
an island about 800 metres off the coast. ${ }^{1}$ Modern Tyre is actually built on a peninsula, due to the silt and sediment that has collected around the moles built from the mainland to the island by Alexander the Great when he conquered the city in $332 \mathrm{BC}$.

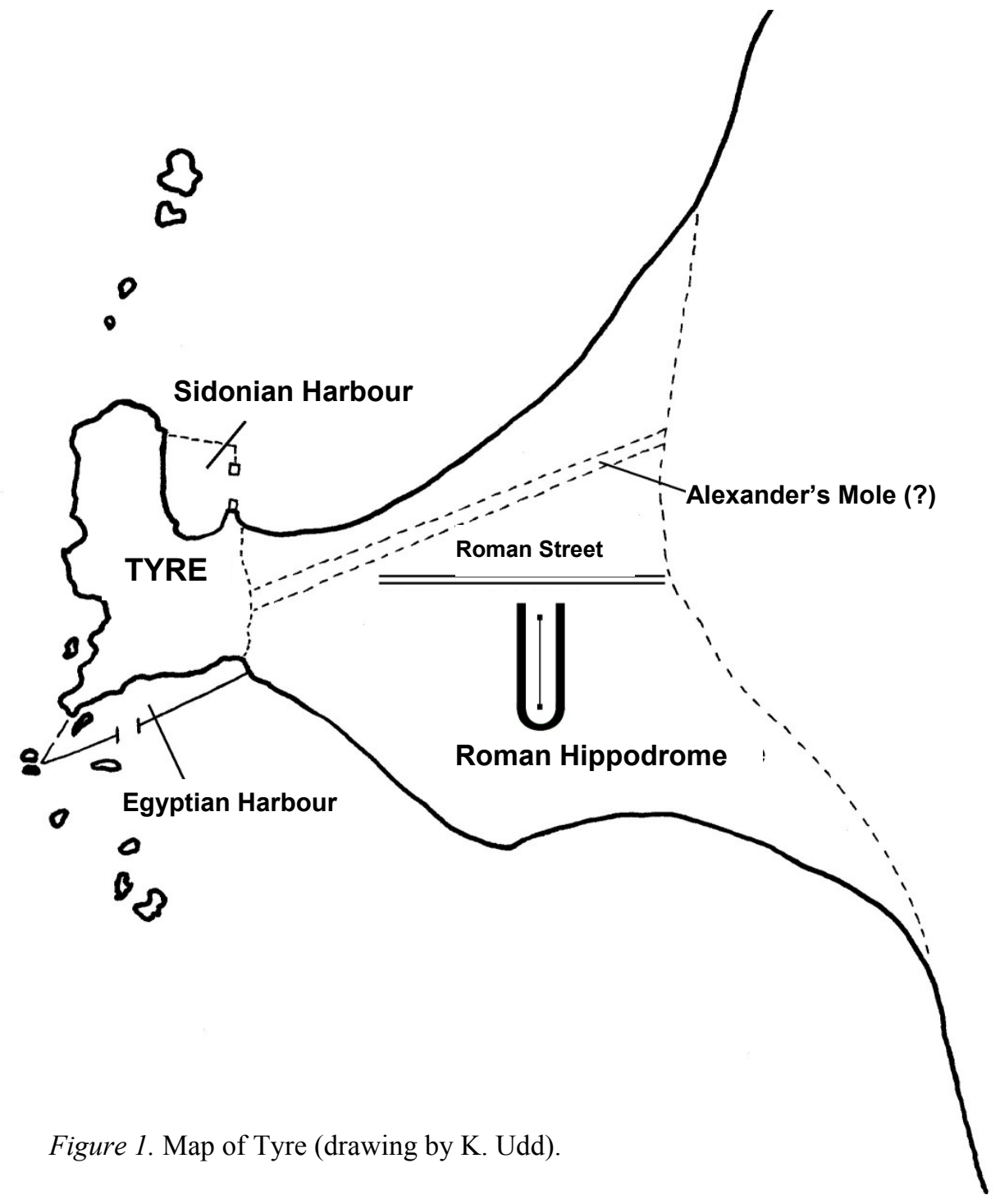

1 A variety of distances are given in the ancient sources, but most are in this general range; H. Jacob Katzenstein, The History of Tyre (Jerusalem: Schocken Institute for Jewish Research, 1973): 10. 
Prior to assessing Ezekiel's prophecy against Tyre, it is critical to establish the exact nature and location of the city. That Tyre lay 'in the midst of the sea' (Ezek. 27:32) ${ }^{2}$ in antiquity is attested by Egyptian, Assyrian, Hebrew, and Greek sources. ${ }^{3}$ For example, one king of Tyre described the city as 'set in the midst of the sea [having] neither water nor wood.' ${ }^{4}$ During the Amarna Age (14th century BC), the Tyrian king Abimilki sent ten letters to Egypt. ${ }^{5} \mathrm{He}$ complained that the king of Sidon had taken over his city on the mainland ('Uzu') and was denying the island inhabitants access to wood, water, and their cemetery. ${ }^{6}$ Tyre's island character is also graphically shown on one of the bronze gates from Balawat, constructed by Shalmaneser III (858-824).

Excavations by Patricia Bikai in 1973-74 showed permanent settlement on the island as early as the Early Bronze II (c. 2700 BC). Unfortunately, 'after level I, dated to around $700 \mathrm{BC}$, the archaeological levels appear to have been destroyed by Roman constructions, which is why there is absolutely no documentation about Middle Iron Age II (725-550 BC) or the Late Iron Age (530-330 BC). ${ }^{7}$

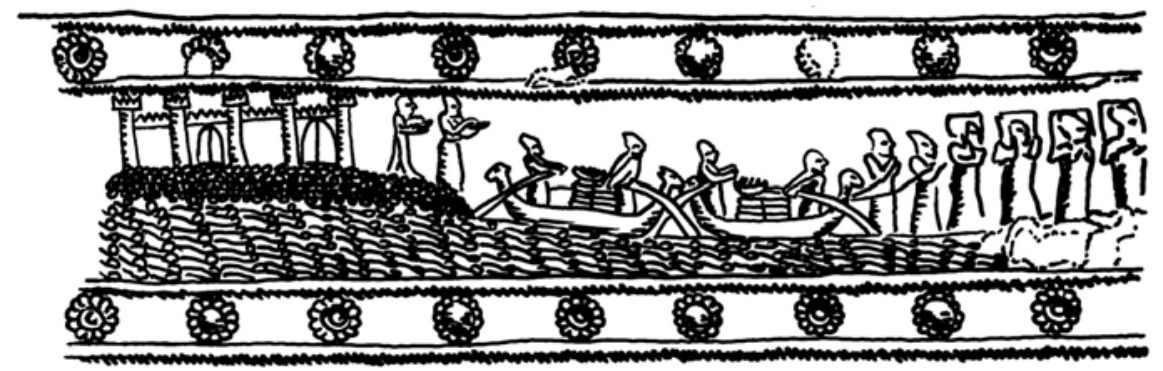

Figure 2. The island city of Tyre as represented on the gates of Balawat. (drawing by K. Udd)

2 Bible quotations throughout this article are from the New American Standard Version.

3 Katzenstein, History of Tyre: 9.

4 El Amarna (EA) text 151. For the full text, see William L. Moran, The Amarna Letters (Baltimore: John Hopkins University Press, 1992): 238-39.

5 EA 146-55.

6 Egyptian and Assyrian texts consistently refer to the mainland city as 'Uzu' or 'Ushu', in distinction from the island city of Tyre; Katzenstein, History of Tyre: 30. See also James Pritchard, Ancient Near Eastern Texts (2nd edn; Princeton: University Press, 1955): 287b, 477a.

7 Maria Aubet, The Phoenicians and the West: Politics, Colonies and Trade (New York: Cambridge University Press, 1987): 291. Further excavations are not feasible due to the location of a modern city atop the ruins. A similar situation exists up the coast at Sidon, although excavations began at Sidon in 1998. These excavations may eventually provide additional information for Tyre as well. A brief update on these excavations may be found in Artifax (Spring 2003): 12-13. 
This is the very period during which Ezekiel prophesied, so until further excavations can be carried out in this populated area, literary evidence is the only source of information for questions about Tyre's fortunes in Ezekiel's day.

\section{Ezekiel's Prophecy}

\subsection{The Presentation of the Prophecy}

Ezekiel first prophesied about Tyre during the final days of the kingdom of Judah. The earliest portions of Ezekiel date to the fifth year of Jehoiachin's exile, about $592 \mathrm{BC} .^{8}$ The prophecy against Tyre came in the eleventh year [of Jehoiachin's exile], or 586 BC. It came on the first day of the first month, a mere three months before the fall of Jerusalem. ${ }^{9}$

Ezekiel's prophecy against Tyre begins in chapter 26. The major motivation for the prophecy seems to have been that the Tyrians intended to take advantage of Jerusalem's impending destruction (v. 2). ${ }^{10}$ In response, God promised to bring about Tyre's destruction by the hand of the same man who would conquer Jerusalem. The relevant and most explicit portion of the prophecy is Ezekiel 26:7-14:

For thus says the Lord GOD, 'Behold, I will bring upon Tyre from the north Nebuchadnezzar king of Babylon, king of kings, with horses, chariots, cavalry, and a great army. He will slay your daughters on the mainland with the sword; and he will make siege walls against you, cast up a mound against you, and raise up a large shield against you. And the blow of his battering rams he will direct against your walls, and with his axes he will break down your towers. Because of the multitude of his horses, the dust raised by them will cover you; your walls will shake at the noise of cavalry and wagons and chariots, when he enters your gates as men enter a city that is breached. With the hoofs of his horses he will trample all your streets. He will slay your people with the sword; and

8 Ezekiel was taken captive to Babylon with Jehoiachin and the royal family in 597 BC. The dates given throughout the book are based on the year of Jehoiachin's exile, e.g. 'the fifth year' is $592 \mathrm{BC}$.

9 Jeremiah records that Jerusalem fell in the fourth month of king Zedekiah's eleventh year (Jer. 39:2).

10 Corral finds Ezekiel's motivation in the fact that 'Judah's economic stagnation was the direct result of Tyre's economic policies and trade practices. Metals and horses were the commodities Judah needed most and Tyre had a practical monopoly over their trade and distribution'; Martin A. Corral, Ezekiel's Oracles Against Tyre (Biblica et Orientalia 46; Rome: Editrice Pontificio Instituto Biblico, 2002): 18. 
your strong pillars will come down to the ground. Also they will make a spoil of your riches and a prey of your merchandise, break down your walls and destroy your pleasant houses, and throw your stones and your timbers and your debris into the water. So I will silence the sound of your songs, and the sound of your harps will be heard no more. And I will make you a bare rock; you will be a place for the spreading of nets. You will be built no more, for I the LORD have spoken,' declares the Lord GOD.

The prophecy goes on at length to describe the reaction of Tyre's neighbours to this unsavoury fate.

Two aspects of the prophecy should be noted. First, Nebuchadnezzar (604-562) was specifically named as God's intended agent of destruction. Not only was Nebuchadnezzar to come and destroy the inhabitants on the mainland, ${ }^{11}$ it was also 'his axes' and 'his horses' that were to be used, and 'he' would slay the people of the city, break down the walls, destroy the houses, and toss the debris into the water.

The other notable aspect of the prophecy is that Tyre's destruction at the hand of Nebuchadnezzar would be a full military conquest followed by destruction. Not only were the inhabitants of the mainland villages doomed, but Tyre itself would be utterly destroyed. Nebuchadnezzar would enter 'your gates as men enter a city that is breached,' his horses would 'trample all your streets', he would 'throw your stones and your timbers and your debris into the water,' with the result that the island would become 'a bare rock', 'a place for the spreading of nets'. The destruction wrought by Nebuchadnezzar was to be so complete that the island would no longer be inhabited.

\subsection{The Fulfilment of the Prophecy}

Nebuchadnezzar did move against Tyre as Ezekiel predicted. A tablet from Babylon records provisions for "the king and the soldiers who went with him against the land of Tyre.' 12 There can be little doubt that Nebuchadnezzar quickly defeated the mainland villages around Tyre. However, he was not successful in taking Tyre itself. Josephus describes a siege of Tyre by Nebuchadnezzar that lasted 13 years (c.

11 Undoubtedly this is a reference to the daughter villages of Tyre that were located on the mainland, including Ushu, Burj, Rachidiyeh, and Cana; see Aubet, The Phoenicians and the West: 31.

12 The tablet was published by E.A. Unger, 'Nebukadnezzar II und sein šandabakku (Oberkommisar) in Tyrus,' Zeitschrift fur die alttestamentliche Wissenschaft 44 (1926): 314-17. The text is quoted from Corral, Ezekiel's Oracles Against Tyre: 61. 
585-572 BC)..$^{13}$ The final result of the siege was inconclusive. Tyre was not defeated, although it became a Babylonian vassal. Zimmerli suggests the existence 'in the city [of] a Babylonian chief commissioner as "keeper of the seal" alongside the king Baal who replaced the rebel Ithobaal. ${ }^{14}$ Some of the royal family moved to Babylon, and from there several were later recalled to rule as kings over Tyre. ${ }^{15}$ Josephus recorded that after the siege ended, Baal II ruled as king of Tyre for another ten years. He was followed by several judges, and eventually three more kings. ${ }^{16}$

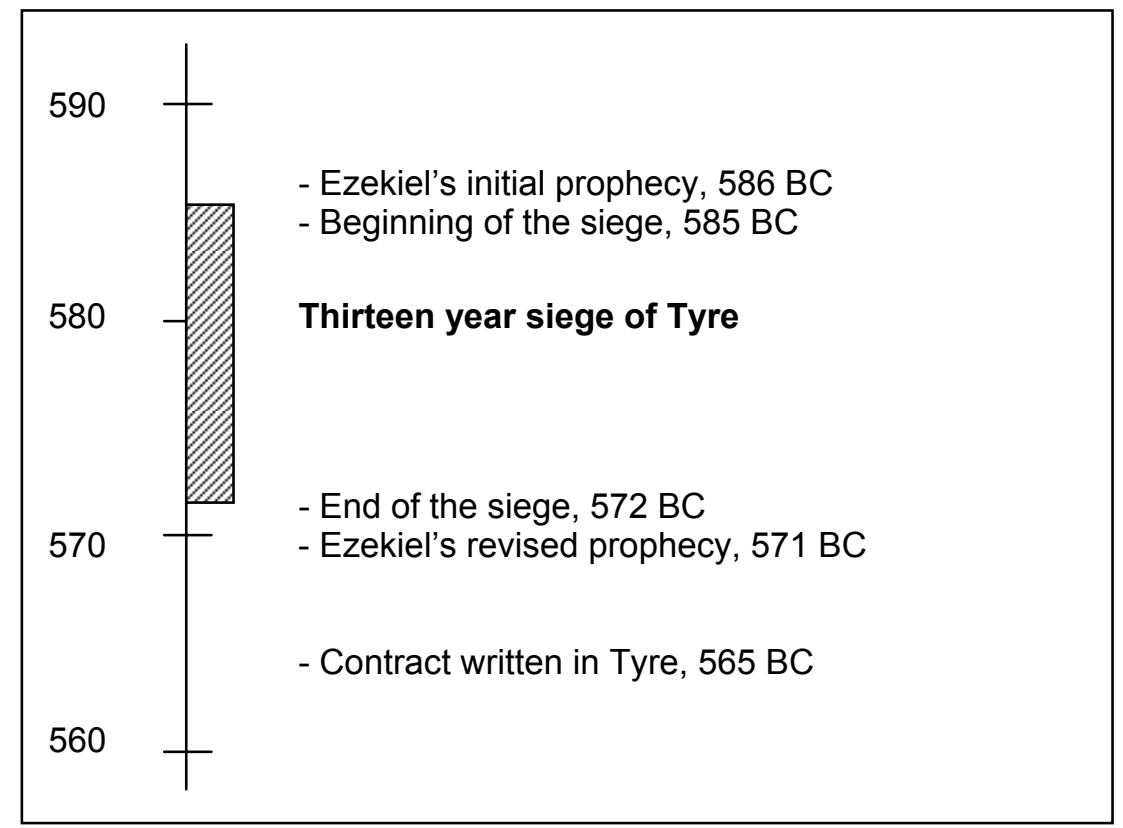

At least two ancient tablets have been discovered that bear witness to the continued existence of Tyre in the days immediately following

\footnotetext{
13 Josephus, Against Apion: 1.21. Zimmerli follows W. B. Fleming and E. Unger in suggesting this set of dates rather than the slightly higher dates of 588/87 to 575/74 suggested by W. F. Albright; see Walther Zimmerli, Ezekiel 2 (Hermeneia; Philadelphia: Fortress Press, 1983; tr. from German, 1969): 118.

14 Zimmerli, Ezekiel 2: 24.

15 These included Baal-ezer III (556 BC), Mahar-baal (555-552 BC), and Hiram III (551-532 BC); see Katzenstein, History of Tyre: 342-44. A helpful discussion of the problems involved in calculating precise dates for Tyrian rulers may be found in Corral, Ezekiel's Oracles Against Tyre: 59, n.160. A 'king of Tyre' is also listed as receiving a pension from the Babylonian court in Nebuchadnezzar's day; see Pritchard, Ancient Near Eastern Texts: 308a.

16 Josephus, Against Apion: 1.21.
} 
the end of Nebuchadnezzar's siege (572 BC). One, which deals with the sale of sesame, is dated December, $570 \mathrm{BC}$ and merely mentions Tyre. The other is a contract actually written in Tyre and dated to the 40th year of Nebuchadnezzar $(565 \mathrm{BC}) .{ }^{17}$ The fact that both tablets were dated according to the reign of Nebuchadnezzar shows definite Babylonian influence in the city. Just as striking is the evidence the tablets provide that the city continued to function as a centre of trade after Nebuchadnezzar's siege. The siege damaged the city and some of her inhabitants were deported, but Tyre was not destroyed. ${ }^{18}$

Further evidence of Tyre's continued existence comes from the Bible itself. According to Ezra 3:7, the Jews who returned to rebuild the temple in Jerusalem some fifty years later hired both Sidonians and Tyrians to bring cedar to Jerusalem. The implication seems to be that the inhabitants of Tyre not only survived the Babylonian siege but also continued to export wood, just as their ancestors had done in the days of Solomon (1 Chr. 22:4). Zechariah, whose prophetic ministry was mainly during 520-518 BC, also prophesied against the city of Tyre, indicating that it still remained in his day (Zech. 9:3). ${ }^{19}$

But perhaps the most telling evidence that Nebuchadnezzar was not successful in his attempt to take Tyre is found in the later testimony of Ezekiel himself. Some sixteen years after Ezekiel's initial prophecy against Tyre, he penned a revision (Ezek. 29:17-20). ${ }^{20}$

Now in the twenty-seventh year, in the first month, on the first of the month, the word of the LORD came to me saying, 'Son of man, Nebuchadnezzar king of Babylon made his army labor hard against Tyre; every head was made bald, and every shoulder was rubbed bare. But he and his army had no wages from Tyre for the labor that he had performed against it.' Therefore, thus says the Lord GOD, 'Behold, I shall give the land of Egypt to Nebuchadnezzar king of Babylon. And he will carry off her wealth, and capture her spoil and seize her plunder; and it will be wages for his army. I have given him the land of Egypt for

17 Katzenstein, History of Tyre: 339.

18 Corral, Ezekiel's Oracles Against Tyre: 61-62, describes evidence of Tyrian deportees which comes from tablets discovered at the Mesopotamian city of Surru, located somewhere between Nippur and Uruk. The tablets are dated to after the siege of Tyre. In addition, Assyrian records show that Tyrian sailors and more than 100 former inhabitants of Tyre were present at Nebuchadnezzar's palace in Nineveh.

19 Many scholars attribute chapters 9-11 to an author working around $300 \mathrm{BC}$, and chapters 12-14 to yet another author around $250 \mathrm{BC}$. Either way, the point is that Tyre continued to exist as a functioning city.

20 Zimmerli follows Parker-Dubberstein in dating this oracle to April 26, 571 BC; Zimmerli, Ezekiel 2: 118. 
his labor which he performed, because they acted for Me,' declares the Lord GOD.

This time the prophecy was not a declaration concerning the fate of Tyre, but a statement about Nebuchadnezzar's unsuccessful attempt to conquer the city. 'He and his army had no wages from Tyre for the labor that he had performed against it' (v. 18). In those days the spoil of a city was considered payment for those who conquered it. In this case payment evaded Nebuchadnezzar and his army, for the city withstood his attack. Because of this, God promised that Nebuchadnezzar would be given Egypt instead, as 'wages for his army ... because they acted for Me.' Nebuchadnezzar moved against Egypt about three years later, although this campaign likewise appears to have been less successful than expected. ${ }^{21}$

In all fairness, it should be noted that before Nebuchadnezzar lifted the siege against Tyre 'he received the nominal submission of the city and the surrender of a number of her nobles.' 22 Furthermore, 'the end of the long siege of Tyre was also the end of a long and glorious history of Tyre.' 23 Tyre would never recover her previous glory, although she would continue to operate as a central trading hub through the Hellenistic, Roman, Byzantine, Early Islamic, and Crusader periods. It is thus fair to say that Ezekiel's initial prophecy against Tyre may have been partially fulfilled, but it fell short of complete fulfilment. ${ }^{24}$ As Zimmerli notes with regard to the revised prophecy in

21 For a historical overview of Nebuchadnezzar's campaign against Egypt, see John Baines and Jaromir Malek, Cultural Atlas of Ancient Egypt (rev. edn; New York: Facts on File, 2000): 51; see also Amélie Kuhrt, The Ancient Near East: c. 3000-330 BC, vol. 2 (New York: Routledge, 1995): 644-45; and Moshe Greenberg, Ezekiel 21-37 (Anchor Bible, 22a; New York: Doubleday, 1997): 617. The Egyptian king Apries (589-570 BC) was ousted by one of his generals, Amasis (570-526 BC) who proclaimed himself king. Apries fled to Babylon and persuaded Nebuchadnezzar to join him in an attempt to retake the throne. The Babylonians attacked Egypt c. 567, but they were repulsed and Apries was killed. If Nebuchadnezzar ever sacked Egypt, evidence of the event has completely eluded both archaeologists and historians. Egypt retained its independence until the battle of Pelusium in $525 \mathrm{BC}$, when it was conquered by the Persian army under Cambyses; on the later periods, see Alan Gardiner, Egypt of the Pharaohs (New York: Oxford University Press, 1961): 361-63. Nebuchadnezzar's failure to take Egypt presents questions similar to those raised here concerning Tyre; cf. Jeremiah's prophecy at about the same time that Nebuchadnezzar would conquer Egypt (Jer. 43:8-13).

22 Nina Jidejian, Tyre Through the Ages (Beirut: Dar el-Mashreq, 1969): 56.

23 Katzenstein, History of Tyre: 337.

24 Thomas Renz, 'Proclaiming the Future: History and Theology in Prophecies against Tyre,' TynBul 51 (2000): 17-58, shows that a similar prophecy against Tyre by Isaiah (ch. 23) met with similar problems. If Isaiah's prophecy relates to Sennacherib's 
chapter 29, 'the real question in the background is the question of divine faithfulness and of the validity of the divine word. ${ }^{25}$

\section{Some Theological Implications}

We now turn to some implications of this prophecy for theology. The three areas we will investigate are closely intertwined: God's way of working in the world, his foreknowledge, and the test of a true prophet. The thread that connects them is the question of the nature of biblical prophecy. Is it simply looking into the future and reporting what is seen, or is it a declaration of what God intends to do? A closely related question is whether the future is fully determined (closed) or only partly determined (open). As we will see, Ezekiel's prophecy seems to nudge us in the direction of the latter.

\subsection{God's modus operandi}

The first question to address concerns God's way of working in the world. Does God always intervene to ensure that his plan comes through? Does he ever adjust his initial plans? It seems that, in the case of Tyre, God was satisfied with a lesser result than what he first declared. On the basis of the Old Testament's understanding of God's sovereignty, it might have been expected that he would have intervened to ensure that his original declaration would come to pass. After all, this is the same God who rained down brimstone and fire on the cities of the plain, and flattened the walls of Jericho. In the case of Tyre though, Tyre was left weakened but standing. Apparently God chose not to intervene and make certain that the prophecy was completely fulfilled. It seems that God would have liked Tyre to be sacked, but nevertheless he preferred to let it survive (less than his ideal) rather than to enforce his ideal through intervention.

This is a thought-provoking observation. Is this to be understood as God's normal way of operating in the world? If so, it might help explain some everyday experiences. Perhaps human circumstances do not always reflect God's will, but what he is willing to put up with.

campaign in $701 \mathrm{BC}$, which seems to be the best fit, it is still the case that the promise 'seems to exceed the fulfillment, even when the oracle is not pressed for absolutely literal fulfillment' (p. 41). Ezekiel's prophecy against Tyre is thus not alone in its failure to be fully realized.

25 Zimmerli, Ezekiel 2: 119 
Sometimes this may involve ugly and difficult things. But it may be a comfort to know that even though bad things happen, that does not necessarily mean they are God's will. ${ }^{26}$

This begs the question of why God is described as operating in this way. Why did he not bring the walls of Tyre crashing down? Why was he willing to stand by and watch Nebuchadnezzar struggle and ultimately fail? Sanders has suggested that this kind of action is in some measure necessary to genuine loving relationships between God and mankind. ${ }^{27}$ Whatever the reason, we can conclude in this case that non-interference was prized over complete fulfilment. Ezekiel presents a God who uses his ability to intervene unilaterally in human affairs less often than he could. Such self-regulation is not presented as inability to act, but is accepted simply as part of God's modus operandi.

\subsection{A Challenge to the Conventional View of Foreknowledge}

The challenge that an unfulfilled prophecy carries for the belief in divine foreknowledge is not small. According to this belief, God knows all future events in exact detail. This is sometimes referred to as definite foreknowledge or determinism. Bruce Ware states that 'without question the most reasonable and only fully satisfying conclusion to draw is that God intends for us to affirm that he knows all of the future.' 28 This echoes the view of Charles Hodge, who unequivocally stated that 'To deny foreknowledge to God, to say that free acts, because necessarily uncertain as to their occurrence, are not the objects of foreknowledge ... is to destroy the very idea of God. ${ }^{29}$ This view certainly fits well with a number of passages in Scripture,

26 This view is defended, for example, by John Sanders, The God Who Risks (Downer's Grove, Illinois: InterVarsity, 1998). Sanders believes that some of the bad things that happen may be categorized as 'gratuitous evil,' and that 'considering the personal aspects of the divine-human relationship, though God works to bring good out of evil, God cannot guarantee that a greater good will arise out of each and every occurrence of evil,' p. 263. A contrary view is that of Iain D. Campbell, 'Open Thoughts on Open Theism,' Scottish Bulletin of Evangelical Theology 21.1 (2003): 44, who espouses a classical theism that 'bows before the throne that knew and ordained and allowed the events of 11 September to occur, and which alone is able to bring good out of disaster.'.

27 Sanders, God Who Risks: esp. ch. 6, 'Risk and Divine Character.'.

28 Bruce Ware, God's Lesser Glory: The Diminished God of Open Theism (Wheaton: Crossway, 2000): 141, emphasis in the original.

29 Charles Hodge, Systematic Theology, abridged edition, ed. Edward N. Gross (Grand Rapids: Baker, 1988): 318. 
especially those in which prophecies have been fulfilled completely and in detail. However, this view does not fare so well in relation to other prophecies. Specifically, why would God declare the destruction of Tyre by Nebuchadnezzar, if his foreknowledge meant that he knew when giving the prophecy that it would not come true? The question of divine foreknowledge and human freedom is hardly new and has been addressed from various angles. ${ }^{30}$ However, the issue in this case is not compatibility versus incompatibility of divine foreknowledge and human freedom, but rather the question of divine foreknowledge and prophecy.

In the past decade or so, a different position has increasingly been endorsed by some evangelical theologians. ${ }^{31}$ According to this view, the future is only partially closed or determined. Since the future does not yet exist, it cannot be completely foreknown. This view has direct implications for prophecy. Renz notes that for the biblical prophet, 'the emphasis is not on God's ability to let his people know beforehand what would happen, but on his power to change world history for the sake of his people.' ${ }^{32}$ Instead of foreknowledge based on the predetermination of all things, 'Knowledge of the future is linked both to a right understanding of the past ... and to the power to accomplish things ... The question is not so much who has the better discernment of the future, but who has the greater power to shape the future.' ${ }^{3}$ Renz has found robust support for this theological perspective particularly in Isaiah. In the same passage where YHWH proclaims his ability to declare the future (46:9-10), he reveals how he is able to do so - 'I have spoken, and I will bring it to pass; I have planned, and I will do it' (46:11). He does not say 'I have seen the future, and this is what is going to happen.' Again a short while later he says, 'The former things I declared long ago, they went out from my mouth and I made them known; then suddenly I did them and they came to pass'

\footnotetext{
30 A recent example is Paul Helm, 'The Augustinian Calvinist View' in Divine Foreknowledge: Four Views, ed. James K. Beilby and Paul R. Eddy (Downer's Grove, Illinois: InterVarsity, 2001): 161-89. Helm advocates a compatibilist position according to which 'there is no need for, and no advantage in, either trying to provide an understanding of human freedom that is indeterministic or trying to argue that such freedom is logically consistent with divine foreknowledge' (p. 163).

31 E.g. Clark Pinnock, The Openness of God (Downers Grove, Ill.: Intervarsity, 1994): 121-24; and David Basinger, The Case for Freewill Theism (Downers Grove, Illinois: InterVarsity, 1996): 55.

32 Renz, 'Proclaiming the Future': 21.

33 Renz, 'Proclaiming the Future': 21, emphasis in the original.
} 
(48:3). In distinction from the false gods, 'Yahweh revealed what he was going to do rather than simply what was going to happen. He is praised not for his passive foreknowledge of events, but his active intervention to bring about his purposes.' 34

If this view is correct, we may conclude that Ezekiel's prophecy against Tyre represented God's intention at the time of the initial prophecy, rather than what he simply foresaw would happen. Ezekiel reveals that God was, for whatever reason, satisfied with Nebuchadnezzar's (less than successful) attempt to sack Tyre. The ethical dilemma faced by the belief in foreknowledge is gone, for the prophet foretold what God actually intended at the time, but subsequently recounted that God settled for a lesser outcome, despite the fact that he could have enforced fulfilment had he wished to do so.

Other theologians reject the idea that God may not have exhaustive definite foreknowledge. They believe that such a view unnecessarily limits God, making him less than infinite, and consequently less than God. However, if it is true that God is the one 'who cannot lie' (Titus $1: 2$; Isa. 40:8), this prophecy would seem to lend support to the view that the future is to some extent open - God spoke of his intention at the time and later decided to amend it. The alternative is an ethical situation that would appear to contradict both scripture and historic Christianity: either God spoke falsely through the prophet, or the prophet is presuming to prophesy on his own. Neither of these options has been viewed as acceptable in historic Christian theology. ${ }^{35}$

\subsection{The Test of a True Prophet}

Deuteronomy 18:22 is a well-known passage that addresses the question of how to tell a false prophet from a true prophet. According to this regulation, 'When a prophet speaks in the name of the LORD, if the thing does not come about or come true, that is the thing which the LORD has not spoken. The prophet has spoken it presumptuously; you shall not be afraid of him.' Ezekiel has been acknowledged throughout the history of the church as a true prophet. What are we to make of the

34 Renz, 'Proclaiming the Future': 21. Renz notes several other passages in Isaiah that carry a similar theme, including Isa. 14:24-27; 41:21-29; 43:14-21; 44:24-28; 45:5-8.

35 There is biblical evidence for the belief that God sometimes deceives (1 Kgs 22:1323; Jer. 4:10; 2 Sam. 24:1; Ezek. 14:9; etc.) However, in the case of Ezekiel and Tyre there is no discernible motive, nor does the text suggest such an answer. On divine deception, see Robert Chisholm, 'Does God Deceive?' Bibliotheca Sacra 155 (1998): $11-28$. 
fact that, by his own admission, one of his prophecies did not come about?

This question has caused some consternation, evidenced by the advancement of some rather imaginative interpretations of Ezekiel's prophecy. Leslie Allen, in the Word Biblical Commentary, concluded that 'an element of rhetorical exuberance was naturally involved in prophesying ... Physical images may be used to convey emotional reality.' ${ }^{36}$ Christopher Wright has employed terms such as 'rhetoric, hyperbole, and stereotyped phraseology' to evoke a similar image. ${ }^{37}$ Daniel Block speaks of a prophetic proclamation 'rhetorically charged with exuberance, passion, hyperbole, figurative language, abstraction, whatever means it will take to evoke a response in the hearer. ${ }^{38}$ Ronald Hals dismissed Ezekiel's description of the fall of Tyre as little more than 'a charming literary touch to establish a logic for the switch from Tyre to Egypt.' 39 The common theme among these statements is that the prophecy was never intended to be understood literally at all. Instead, the prophecy should be viewed as the prophet's emotional outbreak against a bad neighbour. If this interpretive method is accepted, there are certainly hermeneutical ramifications for other prophetic passages as well. How does one differentiate between emotional hyperbole and literal prediction in a prophecy? What marks the line between those parts of a prophecy that were intended to be literally fulfilled and those that were not? Conservative scholars have traditionally viewed fulfilled predictions as evidence that the Bible is from God. If the content of predictive prophecy can so easily be dismissed as nothing more than rhetorical exuberance or stereotyped phraseology, the traditional view of predictive prophecy has been weakened, if not undercut altogether. ${ }^{40}$

Some scholars have suggested that Ezekiel's prophecy was conditional. Christopher Wright has noted that 'biblical prophecy always had a conditional element. That is, predictions of future events

\footnotetext{
36 Leslie C. Allen, Ezekiel 20-48 (Word Biblical Commentary, 29; Dallas: Word, 1990): 111.

37 Christopher J. H. Wright, The Message of Ezekiel (Downer's Grove, Illinois: InterVarsity, 2001): 249.

38 Daniel I. Block, The Book of Ezekiel: Chapters 25-48 (NICOT; Grand Rapids: Eerdmans, 1998): 154.

39 Ronald M. Hals, Ezekiel (Forms of the Old Testament Literature, 19; Grand Rapids: Eerdmans, 1989): 211.

40 I wish to thank John Sanders for this observation.
} 
were made in seemingly absolute terms, but when circumstances changed, or certain responses were made by human beings, God would sometimes not do what was predicted, or would do something quite different.' ${ }^{41}$ Is this a legitimate explanation of Ezekiel 26? It is true that there are cases where prophecies against certain people or cities were conditioned on the population remaining obstinate in their sin (Jon. 3:4-10; Mic. 3:12; cf. Jer. 26:18-20). However, in the case of Tyre there is no indication whatsoever that God changed his mind because anyone repented or because circumstances changed. Wright is correct to point out that God has the freedom to do something quite differently from what he first spoke, and in a sense that can be called conditionality. But it is not the conditionality normally associated with human repentance and God's change of mind (e.g. Jon. 3:10). The strongest indicator that Ezekiel's prophecy was not changed based on human repentance is the fact that God brought Nebuchadnezzar against the city, Nebuchadnezzar worked hard at his appointed task, and afterward God promised him another reward on account of his labour. This seems to show that God's attitude toward Tyre had not significantly changed. Surely Ezekiel would have mentioned the repentance of Tyre, had it in fact occurred. ${ }^{42}$

Another possibility that has been suggested is that the fulfilment of the prophecy was simply delayed. ${ }^{43}$ This may have happened in some other prophecies, especially those that predict judgement but are not specific about the timeframe. One example could be the oracle of Amos against Tyre - 'Thus says the LORD, "For three transgressions of Tyre and for four I will not revoke its punishment, because they delivered up an entire population to Edom and did not remember the covenant of brotherhood. So I will send fire upon the wall of Tyre, and it will consume her citadels"' (Amos 1:9-10). Amos avoids naming an agent

41 Wright, The Message of Ezekiel: 249.

42 This is true for several reasons: 1) unlike Nineveh, there is no record of an Israelite evangelist visiting Tyre to urge repentance, thus there is no obvious source for a call that would lead to repentance; 2) there would be great theological benefit for Ezekiel in referencing the repentance of Tyre, both as an example for Judah and on a broader theological level, yet the prophet is silent on this issue; 3) the later biblical tradition continues to view Tyre as unrepentant [e.g. Zech. 9:3]; and 4) other than Nineveh, there is simply not another example of a foreign people group that repented of sin and turned to YHWH - Nineveh was both a unique and apparently a short-lived example.

43 E.g. Daniel Block, The Book of Ezekiel: 149, stated that 'Yahweh [did] indeed delay the actual fulfillment of the oracle for 250 years, until the time of Alexander the Great.' 
or time for this destruction, so there may at least be some possibility that it was fulfilled by Alexander the Great. ${ }^{44}$ Ezekiel, on the other hand, clearly indicated in his prophecy that God intended Nebuchadnezzar to carry out the task. Once Nebuchadnezzar died the prophecy could no longer be fulfilled as given. In this case, delay of the fulfilment beyond the life of Nebuchadnezzar is not a viable option. ${ }^{45}$

Perhaps the key in coming to grips with this issue is to recognize that Ezekiel himself acknowledged that the prophecy was not completely fulfilled. Interestingly enough, this is not viewed as problematic in Ezekiel. The existing state of affairs is noted, and a reward is specified for Nebuchadnezzar for his trouble. Greenberg has suggested that 'perhaps the most momentous aspect of this amendment is its testimony to the prophet's procedure in the case of invalidated (not merely unfulfilled) prophecies. He did not suppress them, but let them stand in their contradiction to events. He awaited a new message from God to interpret the discrepancy, and when it came, he set it alongside the failed prophecy. ${ }^{46}$

So what conclusion can be drawn concerning the test of a true prophet? Perhaps only this: God can do as he wishes. The role of the true prophet is simply to function as God's mouthpiece. If God decides that it is enough to destroy the economic superiority of a city rather than completely destroying it, even though his initial intention was the latter, so be it. 'Ezekiel knew from personal experience that he was a

44 In Ezekiel's case, however, the complete destruction of the city as prophesied was not even realized by Alexander the Great. Alexander conquered the city and exiled some thirty thousand of its inhabitants, but he left most of the city standing, even making sacrifice in the temple of Heracles. Only eighteen years later the city had to be retaken by Antigonus I; see Jidejian, Tyre Through the Ages: 79-80. Even then the city survived, passing back and forth between the Seleucid and Ptolemaic kings.

45 Renz, 'Proclaiming the Future': 49, responds to the suggestion that only the first part of the prophecy concerned Nebuchadnezzar in this way - 'Vv. 13-14 do not introduce a new actor but underline Yahweh's involvement in Nebuchadrezzar's campaign. In any case, if there is a problem of unfulfilled prophecy, it is not solved by such manoeuvres, as even vv. 8-11 (without vv. 12-14) do not seem to be an accurate description of Nebuchadrezzar's siege and when Tyre was destroyed two and a half centuries later, it was soon rebuilt.'

46 Greenberg, Ezekiel 21-37: 617. Greenberg also makes the penetrating observation that the failed prophecy offers strong evidence of the integrity of the text. 'It is remarkable that the transmitters of these materials also shrank from altering the texts so as to do away with the embarrassing evidence of failure ... the fact that no subsequent addition was made to bring the amendment up to date suggests that the transmitters of the material did not venture to invent oracles for such purposes. Such evidence strongly advises caution in the ascription of material in the Book of Ezekiel to updating by later hands.' 
true prophet, and hence if some of his predictions didn't come out, there had to be a different explanation from the one that would make him a false prophet. His God could change his mind, or some factor might require a shift in strategy, but that was all in the mystery of the Godhead, whereas a prophet ... could only report what he had seen and heard in the heavenly assembly.' 47

This conclusion carries implications for biblical prophecy in general. It may not be necessary (or possible) to point out the exact and complete fulfilment of each prophecy. If God was content in this case with only a partial fulfilment, it is conceivable that this could be true in other cases as well. Much energy has been expended, for example, in attempting to match each detail in Daniel's prophecies to various historical events. Some parts of Daniel's prophecies are remarkable for their detailed and accurate representation of what later occurred (e.g. 11:3-20), while others seem to defy any attempt to match them with historical events (e.g. 11:40-45). ${ }^{48}$ Perhaps Ezekiel offers another alternative for dealing with difficulties of this sort. If our analysis of Ezekiel's prophecy against Tyre is correct, we should hold open the possibility that other prophecies were only partially fulfilled or not fulfilled at all. ${ }^{49}$

\section{Conclusion}

In answer to the initial question of what prophecy really is, there is good evidence to suggest that it is the revelation of what God has

47 David Noel Freedman, editorial comment in Greenberg, Ezekiel 21-37: 617.

48 In the long and contentious history of interpretation of Daniel, all sides have acknowledged the difficulty posed by the latter half of chapter 11 . Preterists solve the difficulty by denying the legitimacy of predictive prophecy, pointing to the lack of alignment of the last half of chapter 11 with historical facts as evidence that it is actual (and wrong) predictive prophecy. Historicists have sought fulfillment in later times (the Roman Empire, the Crusades, or the Roman Catholic papacy), and futurists (especially dispensationalists) posit a chronological gap between the first and last halves of the chapter, linking the latter half with events of the end times that are still future. Representative views include the following: John J. Collins, Daniel (Hermeneia; Minneapolis: Fortress, 1993), preterist; Jacques B. Doukhan, Secrets of Daniel: Wisdom and Dreams of Jewish Prince in Exile (Hagerstown, Maryland: Review and Herald, 2000), historicist; John F. Walvoord, Daniel: The Key to Prophetic Revelation (Chicago: Moody, 1971), futurist.

49 A helpful treatment of this issue is D. Brent Sandy, Plowshares and Pruning Hooks: Rethinking the Language of Biblical Prophecy and Apocalyptic (Downers Grove, Illinois: InterVarsity, 2002). 
planned or intends to do, rather than simply a proclamation of future events based on passive foreknowledge. As Renz puts it, 'prophetic predictions are not historiography before the event but a proclamation of God's purpose.' ${ }^{50}$ It follows, then, that they may be subject to revision.

Ezekiel's God is one who plans and brings things to pass, but is sometimes willing to flex with regard to his intentions. Ezekiel's God 'remains the master of history and also has the power freely to take back apparently unambiguous pronouncements or to let them fade into unimportance.' ${ }^{51}$ Such a view can ease the tension between the test of a true prophet and the failure of a prophecy to be fully realized. Ezekiel was content to record the revised plan concerning Tyre without losing his faith in God or his belief that he was God's true prophet. He remained faithful to his calling as a prophet despite the non-fulfilment of this prophecy. Finally, Ezekiel's prophecy against Tyre may act as a guide in understanding the fulfilment of prophecy in general. Perhaps we should admit more flexibility in the fulfilment of biblical prophecy than has sometimes been granted, allowing that some future events are open, not closed. Such a view seems to fit better with the outlook of Ezekiel, and offers a more satisfying explanation of his otherwise contradictory prophecies.

50 Renz, 'Proclaiming the Future': 17.

51 Zimmerli, Ezekiel 2: 120. 